\title{
Article \\ Experimental Study with Cement Mortars Made with Recycled Concrete Aggregate and Reinforced with Aramid Fibers
}

\author{
Alberto Morón ${ }^{1}$, Daniel Ferrández ${ }^{1}$, Pablo Saiz ${ }^{2}$ and Carlos Morón ${ }^{1, *(\mathbb{D})}$ \\ 1 Departamento de Tecnología de la Edificación, Escuela Técnica Superior de Edificación, \\ Universidad Politécnica de Madrid, 28040 Madrid, Spain; alberto.moron.barrios@alumnos.upm.es (A.M.); \\ daniel.fvega@upm.es (D.F.) \\ 2 Departamento de Economía Financiera, Contabilidad e Idioma Moderno, Universidad Rey Juan Carlos, \\ Campus de Vicálvaro, 28032 Madrid, Spain; pablo.saiz@urjc.es \\ * Correspondence: carlos.moron@upm.es; Tel.: +34-91-336-7583; Fax: +34-91-336-7637
}

check for updates

Citation: Morón, A.; Ferrández, D.; Saiz, P.; Morón, C. Experimental Study with Cement Mortars Made with Recycled Concrete Aggregate and Reinforced with Aramid Fibers. Appl. Sci. 2021, 11, 7791. https:// doi.org/10.3390/app11177791

Academic Editor: Jorge de Brito

Received: 28 July 2021

Accepted: 16 August 2021

Published: 24 August 2021

Publisher's Note: MDPI stays neutral with regard to jurisdictional claims in published maps and institutional affiliations.

Copyright: (c) 2021 by the authors. Licensee MDPI, Basel, Switzerland. This article is an open access article distributed under the terms and conditions of the Creative Commons Attribution (CC BY) license (https:// creativecommons.org/licenses/by/ $4.0 /)$.
Featured Application: This work aims to emphasize the possible applications of construction and demolition waste, performing an experimental analysis on cement mortars made with recycled concrete aggregate and reinforced with aramid fibers. This is especially relevant and innovative, since it focuses on the recovery and reuse of the fraction of fine aggregate smaller than $4 \mathrm{~mm}$ for use in building construction through the manufacture of masonry mortars, in addition to improving its mechanical performance by using aramid fiber as one of the synthetic reinforcements with the greatest future projection in the construction sector. In this way, it seeks to contribute to the Sustainable Development Goals and more specifically to the targets included in Goal 12, that is, to achieve sustainable management and efficient use of natural resources.

Abstract: The reuse of construction and demolition waste is a necessary way to achieve greater sustainability in building, introducing the criteria of the so-called circular economy in the design of the production process of new construction materials. This research focuses on analyzing the properties of mortars made with recycled aggregates from concrete waste and reinforced with aramid fibers. For this purpose, an experimental campaign was carried out, including chemical, physical, mechanical and durability tests, performing a statistical analysis to discuss the different properties analyzed. The results show how the incorporation of aramid fibers in the matrix of cement mortars made with recycled concrete aggregate improves their technical performance and mechanical resistance, thus increasing their application possibilities and achieving similar results in some properties to those obtained with traditional mortars made with natural aggregate.

Keywords: cement mortars; recycled concrete aggregate; aramid fiber; construction

\section{Introduction}

The progressive aging of the building stock in Spain, together with the large number of existing buildings and the high industrial activity of the construction sector, mean that year after year a large amount of Construction and Demolition Waste (CDW) is generated, which must be treated to avoid its accumulation in landfills [1,2]. In Spain alone, more than 21 million tons of CDW are generated per year [3], which means a great environmental impact derived from the waste of these resources that can be recycled and reused as raw materials in the manufacture of mortars and concretes [4,5]. More specifically, the CDW from the demolition of concrete structures can be recycled by mechanical processes to obtain recoverable products suitable for use as raw materials [6]. This is the case of the production plants in charge of manufacturing recycled aggregates, which are an asset of interest for the construction sector due to the large amount of sand demanded in this industrial activity [7], and to the fact that aggregates are the second most consumed natural resource on the planet after water [8]. 
Recycled concrete aggregates are characterized by being essentially composed of two materials: natural aggregate and bonded mortar $[9,10]$, however, these types of aggregates can present impurities such as remains of ceramic materials, metal chips or gypsum and plaster [1]. In general terms, it can be said that recycled concrete aggregates have in comparison with natural aggregates a lower density [11], a higher fines content [12], a higher water absorption [13] and a higher friability coefficient [14]. These characteristics of recycled concrete aggregates have a significant impact on the final properties of masonry mortars made with these materials [15]. In this sense, it can be stated that mortars made with this type of recycled aggregates have, in comparison with traditional mortars made with natural aggregate, a higher coefficient of capillary water absorption [16], higher shrinkage during setting [17], lower mechanical strength [18,19], higher porosity [20] and lower durability [21].

Several researchers are working to improve the properties of these mortars made with recycled aggregates. In this sense, one of the main alternatives is to incorporate reinforcement materials during the mixing process of these mortars [22]. These reinforcing materials are generally added in the form of fibers that can be synthetic or natural [23]. The most commonly used synthetic fibers are glass fibers [24], basalt [25], steel [26], carbon [27] and polypropylene [28], which have demonstrated their technical feasibility to improve the mechanical properties of masonry mortars, especially by increasing their flexural strength and decreasing shrinkage [29]. For their part, the most commonly used natural fibers in the manufacture of mortars are hemp [30], coconut [31] and wood [32] fibers, which have also allowed improving the physical and mechanical properties of masonry mortars, although they generally experience lower durability and greater deterioration with the passage of time [33]. This work is framed within the contributions that study masonry mortars reinforced with synthetic fibers, and more specifically with aramid fibers (Kevlar).

Aramid fibers have good resistance to corrosion and fatigue, which has allowed their application as a reinforcement material in structural construction elements [34,35]. In addition, they have a very good strength/weight ratio, which is approximately five times higher than that of steel [36], and good thermal performance, which enables their use in fire protection studies [37]. On the other hand, these types of fibers are characterized by a high Young's modulus and resistance to abrasion, which together with their ability to form fabrics has allowed extending their industrial possibilities, being used in aerospace, ballistic, composites and cable applications, among others [38]. In recent years, the number of studies related to the incorporation of these types of reinforcement fibers in construction mortars has increased. Thus, Nie et al. observed that aramid fiber presented better properties than carbon fiber to improve the mechanical performance of cement mortars [39], and, on the other hand, Selbi-Acebedo et al. managed to improve the energy absorption capacity, flexural strength and decrease cracking by incorporating polyolefinaramid fibers in the matrix of asphalt mortars [40]. Thus, aramid fiber is positioned with one of the most feasible reinforcement materials to improve the mechanical properties of masonry mortars.

The main objective of this work is to evaluate the physical-mechanical properties of cement mortars made with recycled concrete aggregate and reinforced with aramid fiber. The aim is to improve the technical performance of mortars made with recycled aggregates and their possibilities of use, widening their field of application and bringing their properties closer to those achieved by traditional mortars made with natural aggregates. An experimental campaign was developed where two different dosages were used for each type of mortar, in such a way that it is intended to know which one is more favorable for its application in the building according to the results obtained for the different tests proposed. 


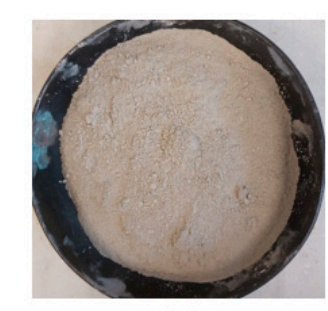

(a)

\section{Materials and Methods}

\subsection{Materials}

This section describes the materials used for the preparation of the different mortar mixes used in this research, which are shown in Figure 1.

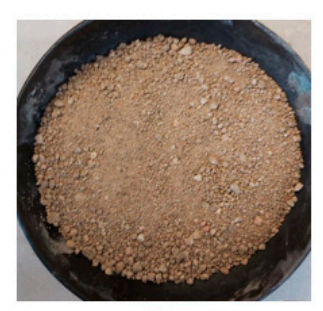

(b)

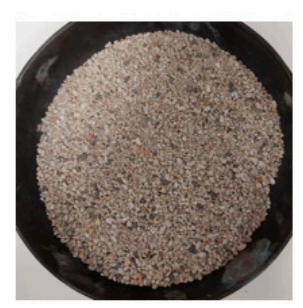

(c)

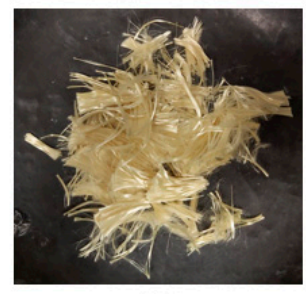

(d)

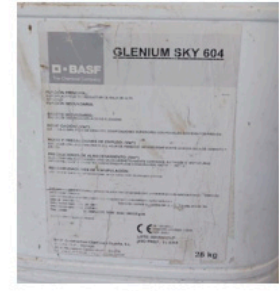

(e)

Figure 1. Materials used. (a) Cement type CEM II/B-L-32.5; (b) natural aggregate (NA); (c) recycled concrete aggregate (RA-Con); (d) aramid fiber; (e) Glenium Sky 604 superplasticizer.

\subsubsection{Cement}

The Instruction for the Reception of Cements (RC-08) is in charge of regulating the different types of cements existing in Spain [41]. Based on this regulation, the hydraulic conglomerate used in this research is of the CEM II/B-L-32.5 N type. It is a cement made up of clinker, limestone and up to $5 \%$ of additions [42], very commonly used on site for economic reasons and for its good technical performance [43]. Table 1 shows the chemical composition of this material obtained by $\mathrm{X}$-ray fluorescence technique.

Table 1. Percentage chemical composition of cement type CEM II/B-L-32.5 N.

\begin{tabular}{|c|c|c|c|c|c|c|c|c|c|c|c|}
\hline $\mathrm{CaO}$ & $\mathrm{SiO}_{2}$ & $\mathrm{SO}_{3}$ & $\mathrm{Al}_{2} \mathrm{O}_{3}$ & $\mathrm{Fe}_{2} \mathrm{O}_{3}$ & $\mathrm{~K}_{2} \mathrm{O}$ & $\mathrm{TiO}_{2}$ & $\mathrm{MgO}$ & $\mathrm{SrO}$ & $\mathrm{BaO}$ & $\mathrm{MnO}$ & $\mathrm{P}_{2} \mathrm{O}_{5}$ \\
\hline 69.80 & 17.05 & 4.21 & 4.10 & 3.45 & 0.66 & 0.24 & 0.23 & 0.08 & 0.07 & 0.07 & 0.04 \\
\hline
\end{tabular}

Among the different oxides that constitute the conglomerating material used in this research and shown in Table 1, those of calcium, silicon, sulfur, iron and aluminum stand out. These components are the majority in the four main phases of these types of cements: Alite (C3S), Belite (C2S), Tricalcium Aluminate (C3A) and Tetracalcium Aluminoferrite (C4AF), obtained in other investigations [44]. Sulfur oxide indicates that there is incorporation of gypsum compounds in the manufacturing process with the aim of reducing the well-known flash setting [45].

\subsubsection{Aggregates}

In this research work, two types of aggregates were used for the manufacture of mortars: natural sand and recycled sand from concrete waste.

Table 2 shows the results derived from the physical characterization of the aggregates following the guidelines of the UNE-EN 13139:2002 standard [46]. To determine these properties, aggregate fractions between 4000 and $0.063 \mathrm{~mm}$ were used, with the exception of fines content and fineness modulus, where particle sizes between the $4000 \mathrm{~mm}$ sieve series and the bottom were used.

Table 2. Physical characterization of the aggregates used.

\begin{tabular}{cccccccc}
\hline Test & $\begin{array}{c}\text { Fine Content } \\
\mathbf{( \% )}\end{array}$ & $\begin{array}{c}\text { Particle } \\
\text { Form }\end{array}$ & $\begin{array}{c}\text { Fineness } \\
\text { Modulus } \mathbf{( \% )}\end{array}$ & $\begin{array}{c}\text { Friability } \\
\mathbf{( \% )}\end{array}$ & $\begin{array}{c}\text { Bulk. Dens, } \\
\mathbf{( K g / \mathbf { m } ^ { 3 } )}\end{array}$ & $\begin{array}{c}\text { Dry Dens. } \\
\left(\mathbf{K g} / \mathbf{m}^{\mathbf{3}}\right)\end{array}$ & $\begin{array}{c}\text { Water Absorption } \\
(\mathbf{\%})\end{array}$ \\
\hline \multirow{2}{*}{ Norma } & UNE EN & UNE-EN & UNE-EN & UNE-EN & UNE-EN & UNE-EN & UNE-EN 1097-6 \\
& $\mathbf{9 3 3 - 1}[47]$ & $\mathbf{1 3 1 3 9}[46]$ & $\mathbf{1 3 1 3 9}[46]$ & $\mathbf{1 4 6 4 0 4}[48]$ & $\mathbf{1 0 9 7 - 3}[49]$ & $\mathbf{1 0 9 7 - 6}[50]$ & {$[50]$} \\
\hline NA & 1.97 & - & 4.35 & 21.12 & 1581 & 2509 & 0.91 \\
RA-Con & 3.73 & Not relevant & 4.08 & 23.17 & 1328 & 2246 & 7.06 \\
\hline
\end{tabular}


As can be seen from the analysis of Table 2, recycled concrete aggregates have a higher fines content than natural aggregates as a result of the crushing and grinding process carried out during their manufacture [51]. On the other hand, it can be seen how the density of the natural aggregate is higher than in the recycled aggregate, which will result in higher mechanical strengths for natural sands [52]. Finally, it should be noted that recycled concrete aggregate has a water absorption coefficient seven times higher than natural aggregate, this has a negative impact through the demand for a greater amount of mixing water in the manufacture of masonry mortars [53].

Figure 2 shows the particle size curves obtained for the aggregates used. A continuous particle size for the sands makes it possible to obtain more homogeneous and workable mortar mixtures [54]. For this reason, the particle size was determined using a series of standardized metallic sieves according to UNE-EN 9332 [55], whose mesh spans are between 4.000 and $0.063 \mathrm{~mm}$.

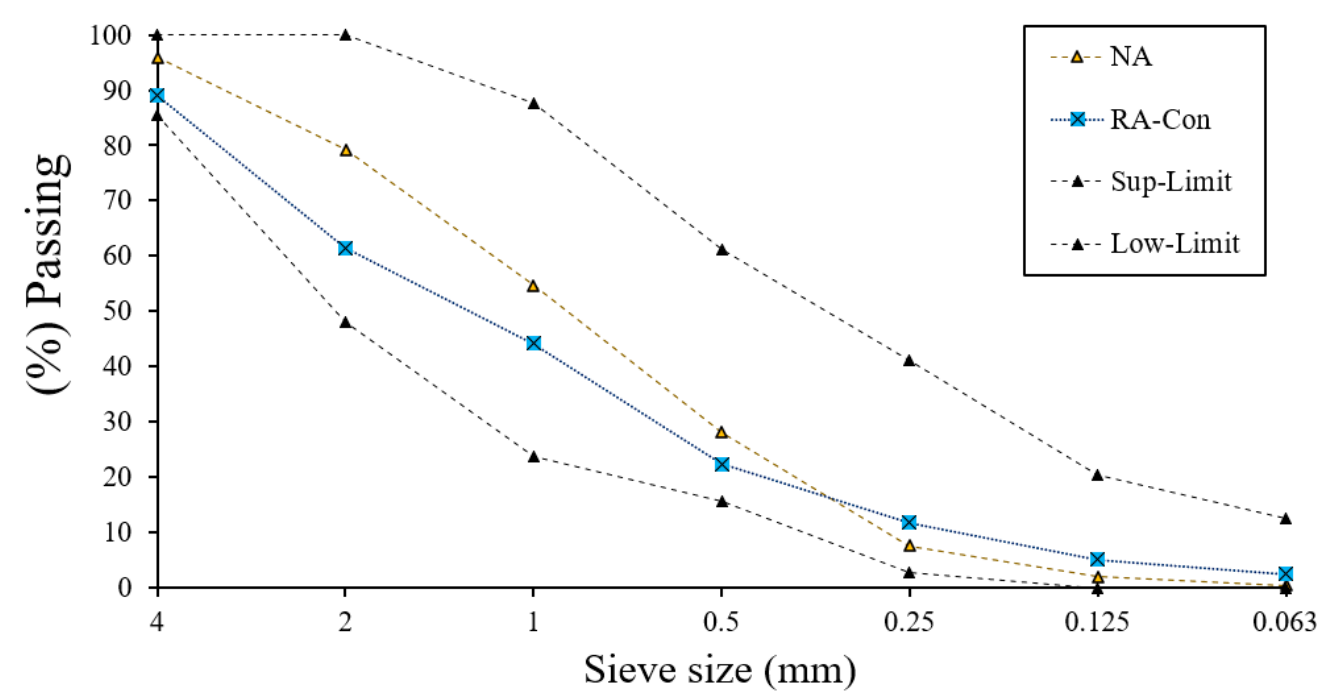

Figure 2. Recycled aggregate size distribution curve compared to the limits of NBE FL-90 [56] adapted to sieve size established by UNE-EN-933-2 [55].

On the other hand, a chemical characterization of the recycled aggregates was carried out to better understand their composition. First of all, a gravimetric thermal analysis was carried out with the aid of an SDT Q600 analyzer, thanks to which it was determined that the calcite content of the recycled concrete aggregates used was $17.55 \%$ and the gypsum particle content was $4.24 \%$. These percentages should be taken into consideration in case the mortars come into contact with steel materials, since a high content of sulfur compounds can accelerate their deterioration [57].

Finally, the elemental chemical composition of the recycled aggregates was analyzed using the X-ray fluorescence (XRF) technique. The results of this analysis are shown in Table 3.

Table 3. Elemental analysis of aggregates by X-ray fluorescence.

\begin{tabular}{ccccccccccccc}
\hline Sample & $\mathrm{Al}_{2} \mathrm{O}_{3}$ & $\mathrm{CaO}$ & $\mathrm{Fe}_{2} \mathrm{O}_{3}$ & $\mathrm{~K}_{\mathbf{2}} \mathrm{O}$ & $\mathbf{M g O}$ & $\mathrm{SiO}_{2}$ & $\mathrm{MnO}$ & $\mathrm{TiO}_{2}$ & $\mathrm{SO}_{3}$ & $\mathbf{P}_{\mathbf{2}} \mathrm{O}_{5}$ & $\mathrm{NaO}_{2}$ & $\mathbf{I} . \mathrm{Loss}_{(\%)}$ \\
\hline RA-Con & 6.12 & 12.05 & 1.81 & 2.11 & 0.53 & 66.2 & 0.02 & 0.16 & - & 0.04 & 0.32 & 10.64 \\
\hline
\end{tabular}

From the chemical analysis presented in Table 3, the high $\mathrm{SiO}_{2}$ content of the recycled concrete aggregates can be highlighted, as a consequence of the natural aggregates used in the manufacture of the concrete [58]. Additionally, a high percentage of calcium oxide is observed as a consequence of the gypsum impurities that were reflected in the gravimetric thermal analysis [59], as well as other minor compounds such as aluminum oxides or iron oxides. 


\subsubsection{Aramid Fiber}

In this work, aramid fibers were used as reinforcement material in the mortars made with recycled aggregate. These synthetic fibers have a high resistance to tensile stresses and are very light, as can be seen in Table 4, through the values supplied by the manufacturer. For this work, fiber percentages of $1 \%$ were added in relation to the volume of mortar, adding these fibers gradually during mixing and ensuring that they were dispersed homogeneously throughout the mortar mass [60].

Table 4. Characteristics of aramid fibers.

\begin{tabular}{cccccccc}
\hline Color & $\begin{array}{c}\text { Length } \\
(\mathbf{m m})\end{array}$ & $\begin{array}{c}\text { Density } \\
\left(\mathbf{k g} / \mathbf{m}^{\mathbf{3}}\right)\end{array}$ & $\begin{array}{c}\text { Tensile Strength } \\
(\mathbf{M P a})\end{array}$ & $\begin{array}{c}\text { Tensile Modulus } \\
\mathbf{( M P a )}\end{array}$ & $\begin{array}{c}\text { Elongation } \\
(\mathbf{\%})\end{array}$ & $\begin{array}{c}\text { Decomposition } \\
\text { Temperature }\left({ }^{\circ} \mathbf{C}\right)\end{array}$ & $\begin{array}{c}\text { Acid/Alkali } \\
\text { Resistance }\end{array}$ \\
\hline Yellow & 20 & 1440 & 3100 & 75 & 3.5 & 157 & Inert \\
\hline
\end{tabular}

It should be noted that a fiber length of $20 \mathrm{~mm}$ was chosen because it is considered optimal for the preparation of mortars, since in the case of using excessively long lengths, agglomerations of fibers in the form of knots may occur during kneading and decreases in mechanical properties, thus generating an effect contrary to the desired one [60].

\subsubsection{Water and Additive}

During the mixing of the cement mortars produced in this study, potable water and a superplasticizer additive were used to improve workability.

Water is the essential component responsible for hydrating the cement and providing the mixture with good workability [61]. For this work, drinking water from the Canal de Isabel II of the Community of Madrid was used, which has the following main characteristics [62]: soft hardness ( $25 \mathrm{mg} \mathrm{CaCO} / \mathrm{l})$, neutral $\mathrm{pH}$ between 7 and 8 recommended to avoid setting alterations and excessive decreases in strength and durability [63], and a chloride content ranging between 1 and $1.5 \mathrm{mg} / \mathrm{L}$ without exceeding the recommended limit for the preparation of mortars [64].

To improve the workability of the mixes made with recycled concrete aggregate, a Glenium Sky 604 superplasticizing additive from BASF was used. This is a component that has been successfully used in previous studies [65], whose raw material is formaldehyde- $\beta$-naphthalensulfonate condensates capable of increasing flocculation capacity. Thanks to the use of this additive, it is possible to improve the properties of the mortar in the fresh state and to reduce the demand for mixing water in recycled mortars, improving the mechanical strength and reducing the possibility of aggregate segregation [66].

\subsection{Methodology}

This section describes the dosages used and the test plan carried out with the mortars used in this research.

\subsubsection{Dosage}

In this work, two different proportions of cement/aggregate ratios by weight were used for each of the two types of sands (natural and recycled) used in this study. In addition, the recommendations of the UNE-EN 1961 standard were followed during the elaboration of the different dosages [67], always with the same techniques and methods and using an IBERTEST planetary mixer, model IB32-040V01. In addition, the following nomenclature was followed in the naming of the mortar specimens:

$$
\text { Aggregate-Ratio-Fiber }
$$

where Aggregate refers to the type of aggregate that can be Natural (NA) or Recycled from concrete waste (RA), Ratio refers to the cement/aggregate ratio that in this work can be 
1:3 or 1:4, and Fiber refers to the type of reinforcement fiber used: without fiber or with aramid fiber (AF).

The different proportions of each raw material used to make the different mixes collected in the study are shown in Table 5.

Table 5. Dosages used for the elaboration of mortars.

\begin{tabular}{ccccccc}
\hline Type & Cement (g) & Aggregate (g) & Water (g) & Fiber (g) & Additive (g) & Consistency (UNE-EN 1015-2: 2007 [68]) \\
\hline NA-1:3 & 450.0 & 1350 & 243 & - & - & 176 \\
NA-1:4 & 337.5 & 1350 & 196 & - & - & 174 \\
RA-1:3 & 450.0 & 1350 & 311 & - & 4.5 & 171 \\
RA-1:4 & 337.5 & 1350 & 250 & - & 3.4 & 169 \\
RA-1:3-AF & 450.0 & 1350 & 311 & 2.5 & 4.5 & 172 \\
RA-1:4-AF & 337.5 & 1350 & 250 & 2.5 & 3.4 & 168 \\
\hline
\end{tabular}

The water content for the different dosages shown in Table 5 was experimentally fixed until a plastic consistency of $175 \pm 10 \mathrm{~mm}$ was achieved according to the UNE-EN 1015-2: 2007 standard [68]. In addition, the superplasticizer additive content corresponds to 1\% by weight of cement, as recommended by the technical department of the BASF company supplying the product [69].

\subsubsection{Experimental Program}

Three well-differentiated blocks of tests were carried out for this work:

- Mechanical characterization tests: flexural and compressive strengths in prismatic specimens of $40 \times 40 \times 160 \mathrm{~mm}^{3}$ according to UNE-EN 101511:2000/A1:2007 [70] and for this purpose, a press model AUTETEST 200-10SW was used, together with an analysis by scanning electron microscopy (SEM), using Jeol JSM820 equipment together with EDX Oxford ISISLink software.

- Physical characterization tests, where the bulk density in hardened state of the mortars, their bond strength (UNE-EN 101512:2016 [71]), capillary water absorption (UNE-EN 101518 [72]) and Shore D surface hardness were determined.

- $\quad$ Durability tests, where the shrinkage during setting in specimens of $25 \times 25 \times 287 \mathrm{~mm}^{3}$ (UNE 8011289 [73]) and the resistance to freeze-thaw cycles in specimens of $40 \times 40 \times$ $160 \mathrm{~mm}^{3}$ (adapted from UNE-EN 12371 [74]) were determined.

On the other hand, in order to determine the effects of the incorporation of aramid fibers on the main properties of recycled mortars, an analysis of variance (ANOVA) was performed. Table 6 shows the factors and levels used for this analysis.

Table 6. Factors and levels used for the analysis of variance (ANOVA).

\begin{tabular}{ccc}
\hline Factors & Levels & Nomenclature \\
\hline Dosage & $1: 3 / 1: 4$ & $\mathrm{~A} / \mathrm{B}$ \\
Fiber type & No Fiber/Aggregate Fiber & NF/AF \\
\hline
\end{tabular}

For each property, the basic assumptions of the model of independence, homoscedasticity and normality of the residuals were tested [75].

\section{Results and Discussion}

This section presents the most relevant results derived from this study together with a statistical discussion of them.

\subsection{Mechanical Characterization Tests}

Masonry mortars must act in the vast majority of their applications as strong bonding elements that share the stresses of the construction system of which they are part [76]. For 
this reason, the flexural and compressive mechanical strengths shown in Figures 3 and 4 were evaluated.
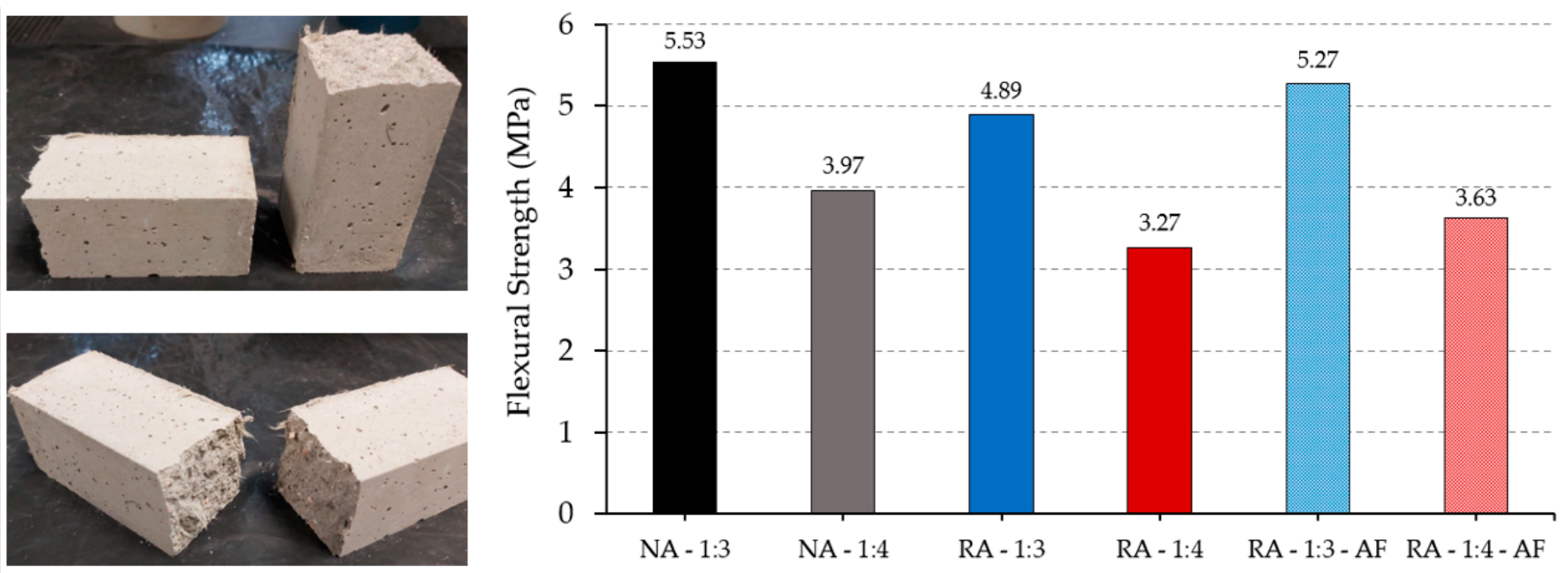

Figure 3. Flexural strength test results and image of specimen RA-1:3-AF type tested.
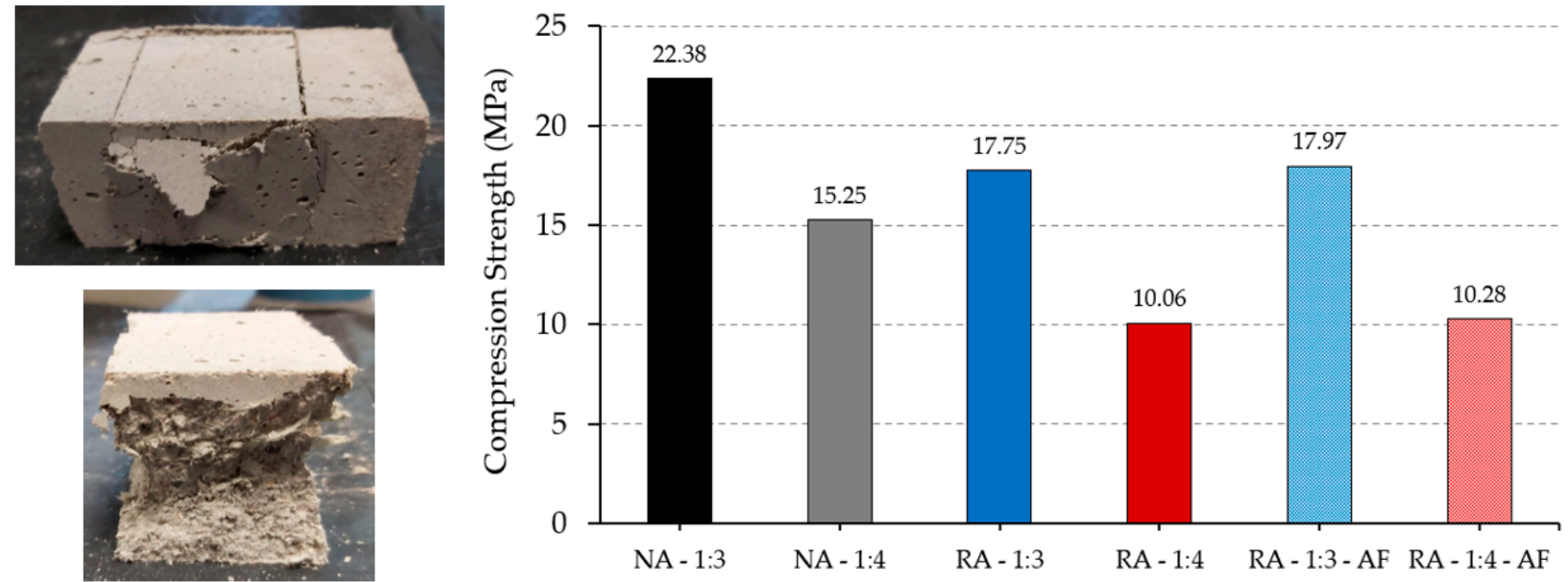

Figure 4. Results of the compressive strength test image of specimen RA-1:3-AF type tested.

As can be seen in Figure 3, the flexural strength of mortars made with natural aggregate is higher than that obtained for mortars made with recycled aggregate, regardless of the cement/aggregate ratio by weight. However, the incorporation of aramid fibers in the mortar matrix has considerably improved the flexural strengths of recycled mortars, with the best results obtained for the RA-1:3-AF mix, since it has a higher cement content [77]. On the other hand, the results of the compression test also show how traditional mortars have higher strengths than recycled mortars, with higher strengths for the mixes with a cement/aggregate ratio of 1:3 by weight. In this case, it can be seen that the addition of fibers in mortars made with recycled concrete aggregate hardly produces an improvement in compressive strength [78]. In addition, in the case of compressive strength, the lower strengths obtained for mortars made with recycled aggregate may be linked to the higher porosity of this type of material, which has been analyzed in depth by other researchers [79].

The analysis of variance (ANOVA) performed to statistically evaluate the effect produced by the incorporation of aramid fibers in mortars made with recycled concrete aggregate is presented in Table 7. 
Table 7. Analysis of variance (ANOVA) for flexural and compressive strength.

\begin{tabular}{|c|c|c|c|c|c|c|}
\hline Property & Source & Sum of Squares & Df & Mean Square & F-Ratio & $p$-Value \\
\hline \multirow[t]{5}{*}{ Flexural Strength $(\mathrm{MPa})$} & A: Dosage & 7.954410 & 1 & 7.954410 & 539.28 & 0.0000 \\
\hline & B: Fiber type & 0.414408 & 1 & 0.414408 & 28.10 & 0.0007 \\
\hline & $\mathrm{AB}$ : Interactions & 0.000075 & 1 & 0.000075 & 0.01 & 0.9449 \\
\hline & Residual & 0.118000 & 8 & 0.014750 & & \\
\hline & Total (Corrected) & 8.486890 & 11 & & & \\
\hline \multirow[t]{5}{*}{ Compression Strength (MPa) } & A: Dosage & 193.218000 & 1 & 193.218000 & 1212.41 & 0.0000 \\
\hline & B: Fiber type & 0.911905 & 1 & 0.911905 & 5.72 & 0.0507 \\
\hline & AB: Interactions & 0.337345 & 1 & 0.337345 & 2.12 & 0.1838 \\
\hline & Residual & 1.274940 & 8 & 0.159367 & & \\
\hline & Total (Corrected) & 195.742000 & 11 & & & \\
\hline
\end{tabular}

As can be seen in Table 7, for the case of flexural strength the two factors included in the study can be considered statistically significant by having a $p$-value below the significance level $(\alpha=0.05)$. However, for the case of mechanical compressive strength, it can be seen how the cement/aggregate ratio can be considered statistically significant $(p$-value $<\alpha)$, but the incorporation of fibers cannot be considered significant for this property.

In Tables 8 and 9 , the results obtained after performing the multiple range test for the mechanical properties are presented.

Table 8. Multi-range test for flexural and compressive mechanical strengths (MPa) considering the cement/aggregate ratio.

\begin{tabular}{cccccc}
\hline Property & Dosage & Count & LS Mean & LS Sigma & Homogeneous Group \\
\hline Flexural Strength & B & 6 & 3.45000 & 0.0495816 & $X$ \\
& A & 6 & 5.07833 & 0.0495816 & $X$ \\
\hline Compression Strength & B & 6 & 10.17130 & 0.1629760 & $X$ \\
& A & 6 & 18.19670 & 0.1629760 & $X$ \\
\hline
\end{tabular}

Table 9. Multi-range test for flexural and compressive mechanical strengths (MPa) considering the incorporation of aramid fibers.

\begin{tabular}{cccccc}
\hline Property & Fiber & Count & LS Mean & LS Sigma & Homogeneous Group \\
\hline Flexural Strength & NF & 6 & 4.08733 & 0.0495816 & $X$ \\
& AF & 6 & 4.45000 & 0.0495816 & $X$ \\
\hline Compression Strength & NF & 6 & 13.9050 & 0.1629760 & $X$ \\
& AF & 6 & 14.1250 & 0.1629760 & $X$ \\
\hline
\end{tabular}

In the multiple range test shown in Tables 8 and 9 for flexural strength, it can be observed that there are significant differences at all levels for each of the factors analyzed. It can be concluded that the mixes incorporating aramid fibers and 1:3 dosage present better performance in terms of this property. However, in the case of compressive strength, it can be seen from the analysis of Table 9 that the incorporation of fibers is not a significant factor in increasing this property.

On the other hand, Figure 5 shows the images obtained by scanning electron microscopy for the mortar samples made with recycled concrete aggregate with and without aramid fibers. 


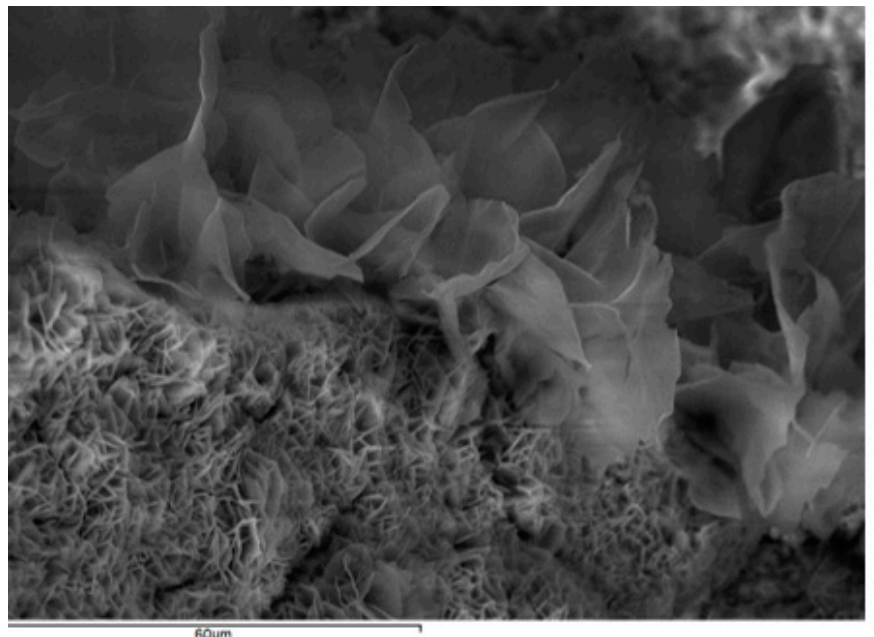

(a)

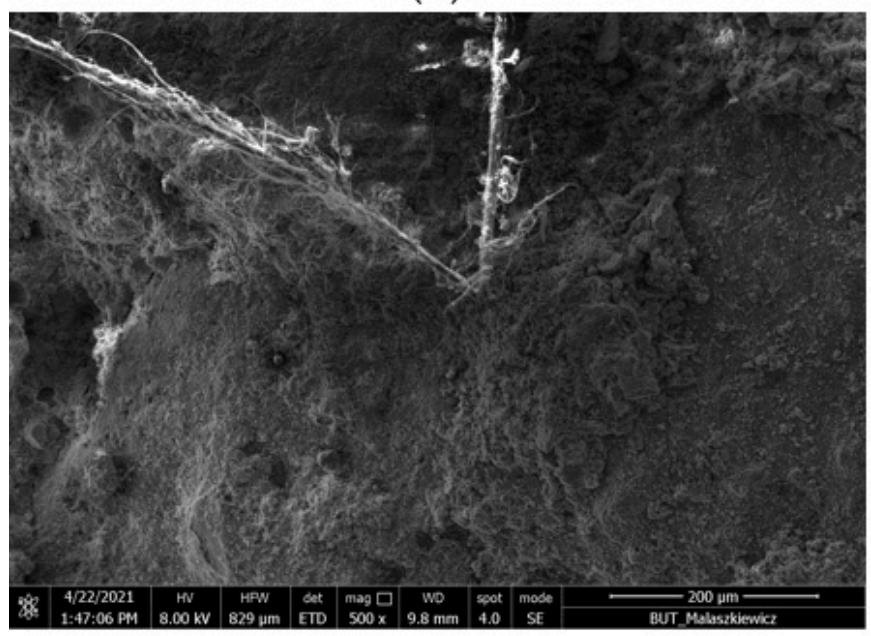

(c)

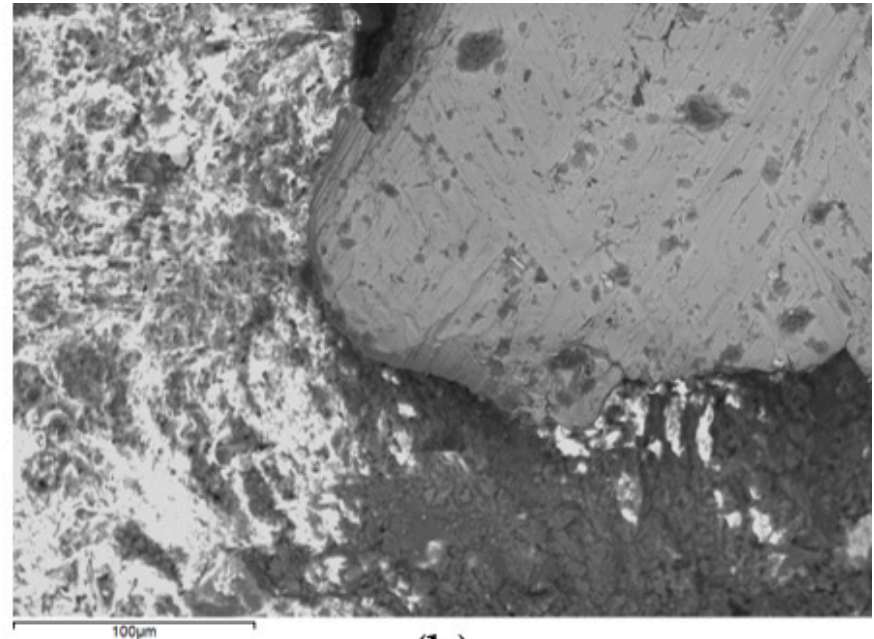

(b)

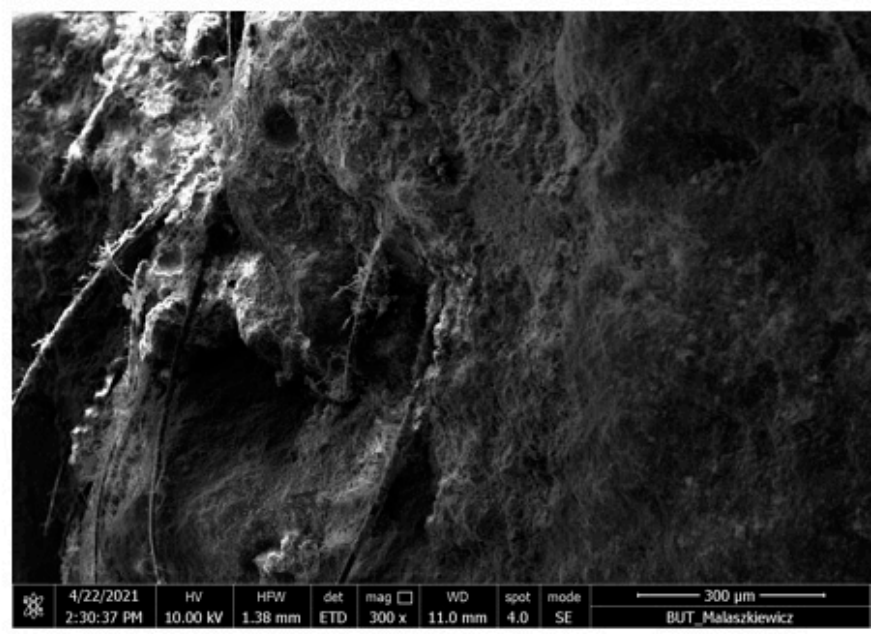

(d)

Figure 5. Scanning electron microscopy: images $(\mathbf{a}, \mathbf{b})$ corresponding to mortar made with recycled concrete aggregate without fibers RA-1:3; images (c,d) corresponding to mortar with recycled concrete aggregate and aramid fiber RA-1:3-AF.

As can be seen in Figure 5a, the mortars made with recycled concrete aggregate have a correct setting process that is reflected by the formation of Ettringite crystals in the mortar matrix [80]. In addition, it can be seen in Figure 5b how the cementitious material wraps and adheres firmly to the surface of the recycled aggregates, resulting in a good cohesion between both. Figure $5 \mathrm{c}$,d shows the interaction between the aramid fiber and the mortar matrix, where it can be appreciated the good mortar-fiber adhesion that has favored the increase of the mechanical flexural strengths [81].

\subsection{Complementary Physical Characterization Tests}

In this section, Table 10 shows the results corresponding to the following properties analyzed: Shore D surface hardness, apparent density of the hardened mortar, adhesion and capillary water absorption.

As shown in Table 10, mortars made with natural aggregate have a higher Shore D surface hardness compared to masonry mortars made with recycled concrete aggregate. In addition, it can be seen how the incorporation of aramid fibers does not produce an improvement in this physical property of the material [82]. Additionally, it is observed that the bond strength of the mortar applied on a brick masonry is reduced in the case of mortars made with recycled aggregate, with worse results in the dosages with a cement/aggregate ratio of 1:4 and with the incorporation of fibers being detrimental to this property [83]. 
Table 10. Results of complementary physical characterization tests.

\begin{tabular}{ccccc}
\hline Type & Hardness (Ud. Shore D) & Bulk Density $\mathbf{( k g / \mathbf { m } ^ { 3 } )}$ & Adherence (MPa) $\left.^{\text {Absorption }\left(\mathbf{k g} / \mathbf{m m}^{\mathbf{2}} \mathbf{m i n}\right.} \mathbf{0 . 5}^{\mathbf{3}}\right)$ \\
\hline NA-1:3 & 81.7 & 2093 & 0.52 & 0.53 \\
NA-1:4 & 77.0 & 1993 & 0.57 & 0.58 \\
RA-1:3 & 72.7 & 1831 & 0.42 & 0.67 \\
RA-1:4 & 70.7 & 1754 & 0.38 & 0.76 \\
RA-1:3-FA & 71.7 & 1855 & 0.36 & 0.61 \\
RA-1:4-FA & 71.0 & 1776 & 0.32 & 0.72 \\
\hline
\end{tabular}

Regarding the bulk density of the mortars, it can be seen that mortars made with recycled aggregate are lighter than traditional mortars. This greater lightness can be attributed to a greater porosity of the mortars made with recycled concrete aggregate, which in turn has been manifested in a decrease of the flexural and compressive mechanical properties [84]. Finally, and in agreement with the aggregate characterization tests, it can be observed that mortars made with recycled concrete aggregate have a higher capillary water absorption than mortars with natural aggregate, although this higher capillary absorption is reduced in the recycled mortar mixes made with aramid fiber. This higher absorption can have a negative impact on the formation of pathologies derived from dampness that can be difficult to correct [85].

After analyzing Table 11, it can be seen that for the properties of adhesion and water absorption by capillarity, there are statistically significant differences for the two factors included in the study, since they have a $p$-value below the significance level $(\alpha=0.05)$. However, in the case of bulk density and surface hardness, the only significant factor is the cement/aggregate ratio.

Table 11. Analysis of variance (ANOVA) for flexural and compressive mechanical strengths.

\begin{tabular}{|c|c|c|c|c|c|c|}
\hline Property & Source & Sum of Squares & Df & Mean Square & F-Ratio & $p$-Value \\
\hline \multirow[t]{5}{*}{ Hardness (Ud. Shore D) } & A: Dosage & 21.33333 & 1 & 21.33333 & 5.82 & 0.0424 \\
\hline & B: Fiber type & 0.33333 & 1 & 0.33333 & 0.10 & 0.7655 \\
\hline & AB: Interactions & 1.33333 & 1 & 1.33333 & 0.38 & 0.5543 \\
\hline & Residual & 28.0000 & 8 & 3.50000 & & \\
\hline & Total (Corrected) & 35.0000 & 11 & & & \\
\hline \multirow[t]{5}{*}{ Bulk Density $\left(\mathrm{kg} / \mathrm{m}^{3}\right)$} & A: Dosage & $18,174.10$ & 1 & $18,174.100$ & 48.47 & 0.0001 \\
\hline & B: Fiber type & 1564.08 & 1 & 1564.080 & 4.17 & 0.0754 \\
\hline & AB: Interactions & 6.75 & 1 & 6.750 & 0.02 & 0.8966 \\
\hline & Residual & 2999.33 & 8 & 374.917 & & \\
\hline & Total (Corrected) & $22,744.30$ & 11 & & & \\
\hline \multirow[t]{5}{*}{ Adherence (MPa) } & A: Dosage & 0.00480 & 1 & 0.00480 & 36.00 & 0.0003 \\
\hline & B: Fiber type & 0.01080 & 1 & 0.01080 & 81.00 & 0.0000 \\
\hline & AB: Interactions & 0.00013 & 1 & 0.00013 & 1.00 & 0.3466 \\
\hline & Residual & 0.00107 & 8 & 0.00013 & & \\
\hline & Total (Corrected) & 0.01680 & 11 & & & \\
\hline \multirow[t]{5}{*}{ Absorption $\left(\mathrm{kg} / \mathrm{mm}^{2} \min ^{0.5}\right)$} & A: Dosage & 0.02901 & 1 & 0.02901 & 145.04 & 0.0000 \\
\hline & B: Fiber type & 0.00701 & 1 & 0.00701 & 35.04 & 0.0004 \\
\hline & AB: Interactions & 0.00007 & 1 & 0.00007 & 0.37 & 0.5573 \\
\hline & Residual & 0.00160 & 8 & 0.00020 & & \\
\hline & Total (Corrected) & 0.03769 & 11 & & & \\
\hline
\end{tabular}

Thus, the results of the ANOVA analysis support the discussion in Table 10. The results obtained for the multiple range tests are presented in Tables 12 and 13. 
Table 12. Multiple range test for complementary tests considering the cement/aggregate ratio.

\begin{tabular}{|c|c|c|c|c|c|}
\hline Property & Dosage & Count & LS Mean & LS Sigma & Homogeneous Group \\
\hline \multirow[t]{2}{*}{ Hardness (Ud. Shore D) } & B & 6 & 74.00 & 0.781736 & $x$ \\
\hline & A & 6 & 76.66 & 0.781736 & $x$ \\
\hline \multirow[t]{2}{*}{ Bulk Density $\left(\mathrm{kg} / \mathrm{m}^{3}\right)$} & B & 6 & 1765.33 & 7.904820 & $x$ \\
\hline & A & 6 & 1843.17 & 7.904820 & $x$ \\
\hline \multirow[t]{2}{*}{ Adherence (MPa) } & B & 6 & 0.35 & 0.004714 & $x$ \\
\hline & A & 6 & 0.39 & 0.004714 & $x$ \\
\hline \multirow[t]{2}{*}{ Absorption $\left(\mathrm{kg} / \mathrm{mm}^{2} \mathrm{~min}^{0.5}\right)$} & $\mathrm{A}$ & 6 & 0.640 & 0.005774 & $x$ \\
\hline & B & 6 & 0.738 & 0.005774 & $X$ \\
\hline
\end{tabular}

Table 13. Multi-range test the complementary tests considering the incorporation of aramid fibers.

\begin{tabular}{cccccc}
\hline Property & Fiber & Count & LS Mean & LS Sigma & Homogeneous Group \\
\hline Hardness (Ud. Shore D) & NF & 6 & 71.70 & 0.781736 & $X$ \\
& AF & 6 & 71.35 & 0.781736 & $X$ \\
\hline Bulk Density $\left(\mathrm{kg} / \mathrm{m}^{3}\right)$ & NF & 6 & 1792.83 & 7.90482 & $\mathrm{X}$ \\
& AF & 6 & 1815.67 & 7.90482 & $\mathrm{X}$ \\
\hline Adherence $(\mathrm{MPa})$ & AF & 6 & 0.34 & 0.004714 & $\mathrm{X}$ \\
& NF & 6 & 0.40 & 0.004714 & $X$ \\
\hline Absorption $\left(\mathrm{kg} / \mathrm{mm}^{2} \mathrm{~min}^{0.5}\right)$ & NF & 6 & 0.665 & 0.005774 & $X$ \\
& AF & 6 & 0.713 & 0.005774 & $X$ \\
\hline
\end{tabular}

As can be seen in Table 12, for the multiple range test considering the dosage factor that takes into account the cement/aggregate ratio, there are significant differences for all the tests performed. Thus, it can be stated that by increasing the cement/aggregate ratio from 1:3 to 1:4, all the properties studied in this section decrease [86]. However, after the analysis of Table 13, it can be seen that the incorporation of fibers is only a significant factor in the case of adhesion, where it has a negative influence on this property, and for water absorption by capillarity, where the incorporation of aramid fibers is beneficial for mortars made with recycled concrete aggregate.

As can be seen in Figure 6, all the samples tested obtained a decrease in their mechanical flexural strength when subjected to the 25 freeze-thaw cycles compared to identical samples of the same age and without cycles. It can be seen in Table 14 how this decrease in strength and mass loss is greater in mortars made with recycled concrete aggregate than for traditional mortars. In addition, the beneficial effect of incorporating aramid fibers in the mortar matrix is also evident, since the mixes made with recycled aggregate and incorporation of fibers showed similar flexural strength results to the mortars made with natural aggregate and obtained even lower mass losses than the traditional mortars.

Table 14. Loss of mass in grams and percentage decrease in flexural mechanical strength of specimens subjected to freeze-thaw cycling [74].

\begin{tabular}{cccccccc}
\hline Property & NA-1:3 & NA-1:4 & RA-1:3 & RA-1:4 & RA-1:3-FA & RA-1:4-FA \\
\hline $\boldsymbol{\nabla}$ Mass (g) & 9.73 & 11.73 & 15.43 & 19.03 & 11.30 & 16.03 \\
\hline $\boldsymbol{\nabla}$ Flexural Strength (\%) & 4.49 & 5.80 & 6.31 & 8.67 & 3.84 & 5.38 \\
\hline
\end{tabular}




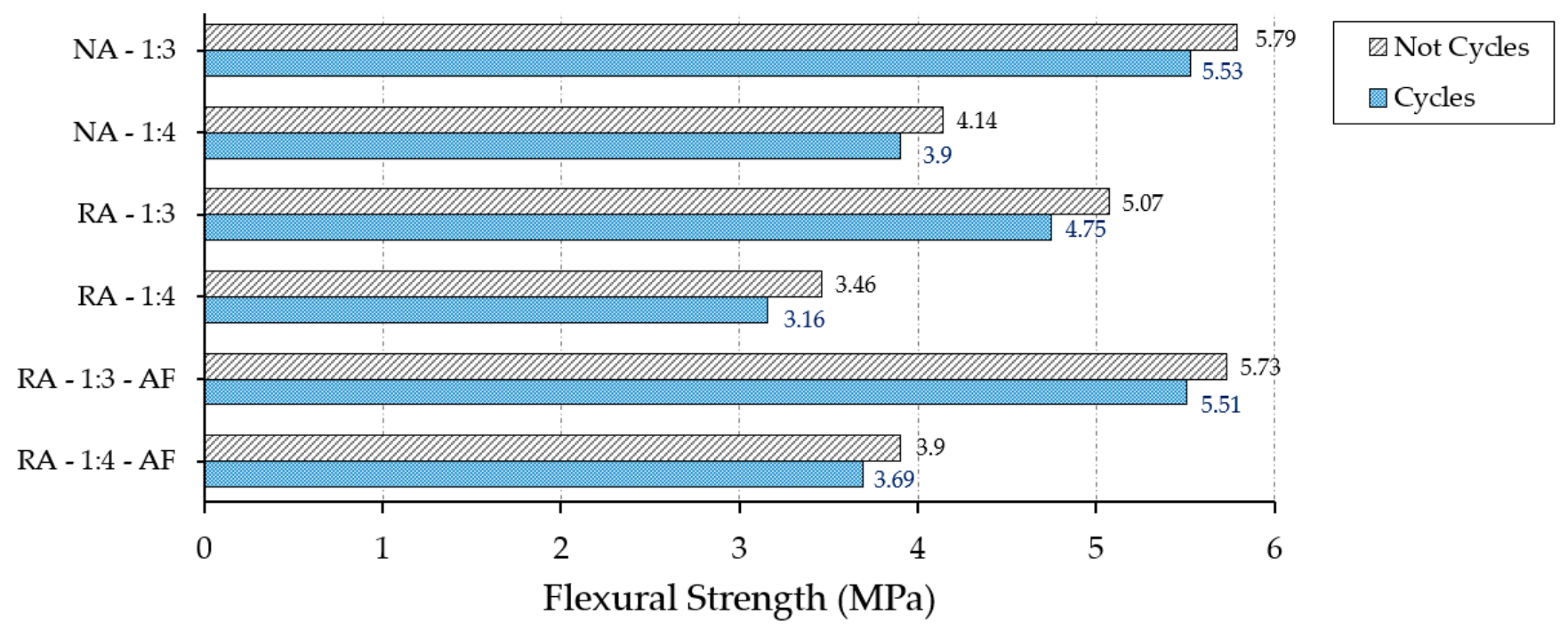

Figure 6. Flexural strength test results derived from the freezing test for cycled and uncycled specimens.

Figure 7 shows the results of the shrinkage test measured over a period of 100 days.

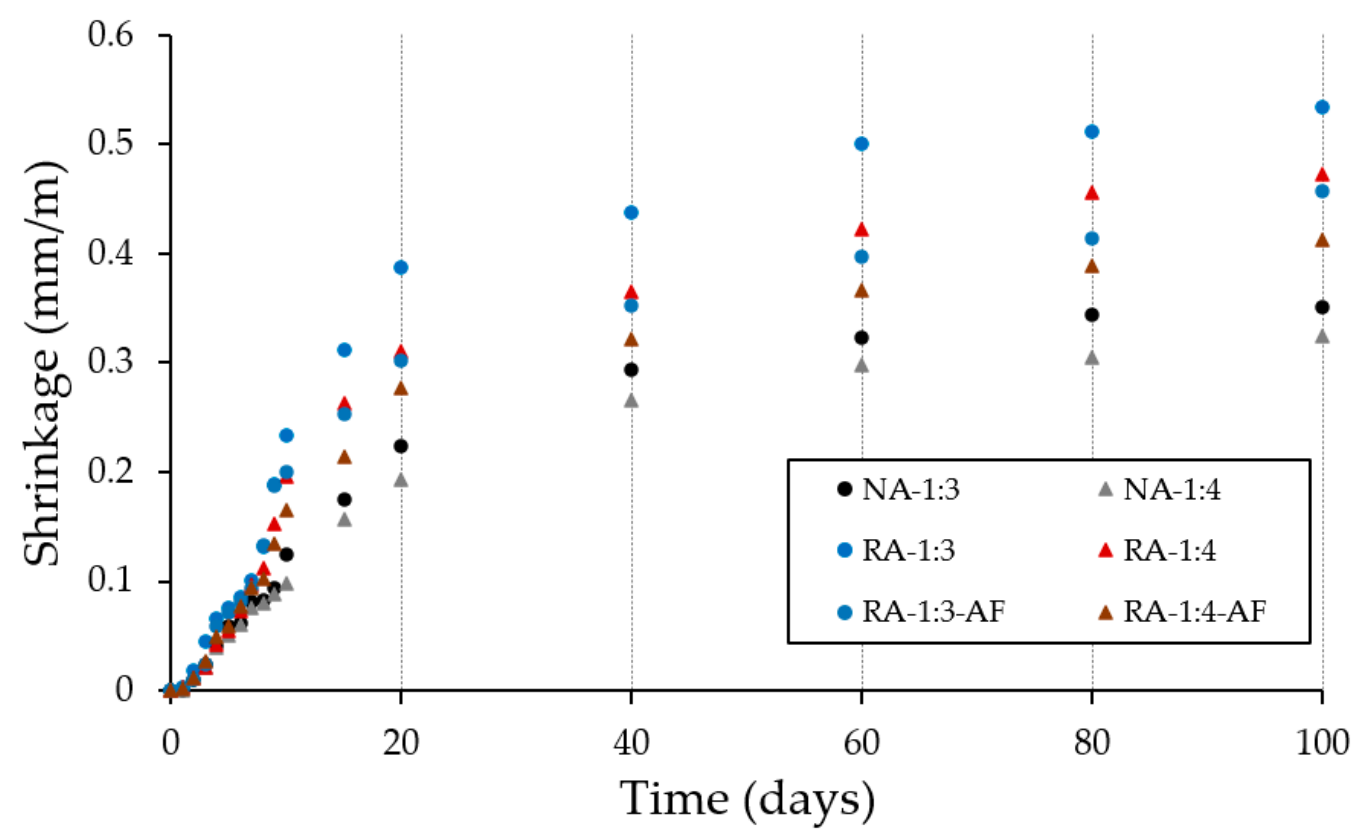

Figure 7. Shrinkage evolution $(\mathrm{mm} / \mathrm{m})$ during setting evolution (days).

As can be seen in Figure 7, mortars made with natural aggregate have a lower shrinkage during setting and have a higher dimensional stability for the same period of time in agreement with other previous studies [87]. On the other hand, the positive effect offered by the incorporation of aramid fibers to the mortar matrix made with recycled concrete aggregate can be appreciated, since it reduces shrinkage and hinders the appearance of cracks during setting [88]. It can also be seen how the dosages with a cement/aggregate ratio by weight of 1:4 have a lower shrinkage, which is due to their lower cement content and the RA-1:4-AF dosage being the one that is closest to the traditional mortar.

The analysis of variance (ANOVA) performed for the statistical discussion of the durability tests on mortars made with recycled concrete aggregate is presented in Table 15. 
Table 15. Analysis of variance (ANOVA) for shrinkage and freezing tests.

\begin{tabular}{|c|c|c|c|c|c|c|}
\hline Property & Source & Sum of Squares & Df & Mean Square & F-Ratio & $p$-Value \\
\hline \multirow[t]{5}{*}{ Shrinkage $(\mathrm{mm} / \mathrm{m})$} & A: Dosage & 0.0083003 & 1 & 0.0083003 & 78.49 & 0.0000 \\
\hline & B: Fiber type & 0.0137499 & 1 & 0.0137499 & 130.02 & 0.0000 \\
\hline & AB: Interactions & 0.0002219 & 1 & 0.0002219 & 2.10 & 0.1855 \\
\hline & Residual & 0.0008460 & 8 & 0.0001058 & & \\
\hline & Total (Corrected) & 0.0231180 & 11 & & & \\
\hline Freeze/Thaw Resistance: & A: Dosage & 0.0001333 & 1 & 0.0001333 & 0.03 & 0.8734 \\
\hline \multirow[t]{4}{*}{ Flexural Strength (MPa) } & B: Fiber type & 0.0280333 & 1 & 0.0280333 & 5.69 & 0.0441 \\
\hline & $\mathrm{AB}$ : Interactions & 0.0000333 & 1 & 0.0000333 & 0.01 & 0.9365 \\
\hline & Residual & 0.0394000 & 8 & 0.0049250 & & \\
\hline & Total (Corrected) & 0.0676000 & 11 & & & \\
\hline
\end{tabular}

As can be seen, after the analysis of Table 15, for the case of shrinkage, both factors, type of aggregate and incorporation of fibers, are statistically significant for the study, since they have a $p$-value lower than the significance level. This result is in agreement with the graph in Figure 7, where it can be seen that the dosages with cement/aggregate ratio 1:3 have a higher shrinkage and that it decreases with the incorporation of aramid fibers. However, in the case of durability under freeze-thaw cycles, the only significant factor for the analysis is the incorporation of aramid fibers, this reinforcement material being beneficial for the mechanical flexural strengths and statistically proven. On the other hand, in this case the cement/arid dosage is not statistically significant because, as can be seen in all the samples, there is a loss of mass which in turn is associated with a loss of flexural mechanical strength.

Finally, and in accordance with the previous analyses, Tables 16 and 17 show the results obtained for the multiple range tests on mortars made with recycled concrete aggregate.

Table 16. Multi-range test for shrinkage and flexural strength considering the cement/aggregate ratio.

\begin{tabular}{cccccc}
\hline Property & Dosage & Count & LS Mean & LS Sigma & Homogeneous Group \\
\hline Shrinkage $(\mathrm{mm} / \mathrm{m})$ & $\mathrm{B}$ & 6 & 0.44265 & 0.00419821 & $\mathrm{X}$ \\
& $\mathrm{A}$ & 6 & 0.49525 & 0.00419821 & $\mathrm{X}$ \\
\hline Freeze/Thaw Resistance: & $\mathrm{B}$ & 6 & 0.25667 & 0.02865020 & $\mathrm{X}$ \\
Flexural Strength $(\mathrm{MPa})$ & $\mathrm{A}$ & 6 & 0.26333 & 0.02865020 & $\mathrm{X}$ \\
\hline
\end{tabular}

Table 17. Multi-range test for shrinkage and flexural strength considering the incorporation of aramid fibers.

\begin{tabular}{cccccc}
\hline Property & Fiber & Count & LS Mean & LS Sigma & Homogeneous Group \\
\hline Shrinkage $(\mathrm{mm} / \mathrm{m})$ & AF & 6 & 0.43510 & 0.00419821 & $\mathrm{X}$ \\
& NF & 6 & 0.05028 & 0.00419821 & $\mathrm{X}$ \\
\hline Freeze/Thaw Resistance: & AF & 6 & 0.21167 & 0.02865020 & $\mathrm{X}$ \\
Flexural Strength $(\mathrm{MPa})$ & NF & 6 & 0.30833 & 0.02865020 & $\mathrm{X}$ \\
\hline
\end{tabular}

Table 16 shows how for the multiple range test considering the dosage factor (cement/aggregate ratio), there are only significant differences in the homogeneous groups for the case of shrinkage. However, in Table 17, it can be seen how the analysis of homogeneous groups for the incorporation of fibers shows that for the durability properties studied, the incorporation of aramid fibers in the mortar matrix improves the performance of recycled mortars. 


\section{Conclusions}

In recent decades, the efficient management of CDW has become one of the major challenges for the construction industry, which is increasingly aware of the need to protect the natural environment and make better use of natural resources. In the present research, progress was made in the state of knowledge of recycled aggregates from waste concrete, and some of their possibilities for the elaboration of masonry mortars reinforced with aramid fiber were shown. More specifically, the mechanical, physical and durability properties of this type of cement mortars were evaluated.

Regarding the mechanical properties, it was observed that the incorporation of aramid fibers significantly improves the flexural strengths of cement mortars made with recycled concrete aggregate. In addition, the dosages with a cement/sand ratio of 1:3 by weight showed better results than the mixes made with a 1:4 ratio. However, although the incorporation of aramid fibers improves the mechanical strengths of the recycled mortars, they do not reach the flexural strengths of traditional mortars made with natural aggregate. On the other hand, the incorporation of aramid fibers has not significantly improved the compressive strength of the mortars made with recycled aggregate. The microscopy tests carried out show good fiber-matrix adhesion and good cohesion of the material.

As for the physical properties, it should be noted that the incorporation of aramid fiber has only led to an improvement by decreasing the capillary water absorption in the mortars made with recycled aggregate. On the other hand, the adhesion of mortars with aggregate from concrete waste was reduced by incorporating reinforcement fibers. Aggregate density and surface hardness are not affected by the incorporation of fibers into the mortar matrix. In addition, it was shown that mortars with natural aggregate presented better physical properties and how these properties improve for dosages with higher cement content.

In the durability tests, there were significant improvements in the mortars made with recycled aggregates that incorporated aramid fibers. More specifically, greater resistance to freeze-thaw cycles was achieved by incorporating reinforcing fibers, increasing the mechanical strength of the recycled mortars and decreasing the loss of mass produced during the freezing test. On the other hand, the shrinkage of mortars with recycled concrete aggregate and aramid fiber also decreases with respect to recycled mortars without fibers. Thus, it can be affirmed that mortars with recycled aggregate and reinforcing fibers have greater dimensional stability and shrinkage decreases to values close to those of traditional mortars made with natural aggregate.

Finally, it should be noted that this study is part of the contributions aimed at promoting clean production through the efficient use of natural resources, as stated in the European Agenda 2030.

Author Contributions: Conceptualization, D.F. and P.S.; methodology, D.F.; software, D.F. and P.S.; validation, D.F., C.M. and A.M.; formal analysis, C.M.; investigation, D.F.; resources, C.M.; data curation, P.S. and A.M.; writing — original draft preparation, D.F.; writing—review and editing, A.M.; visualization, A.M.; supervision, C.M.; project administration, C.M.; funding acquisition, C.M. All authors have read and agreed to the published version of the manuscript.

Funding: This research received no external funding.

Institutional Review Board Statement: Not applicable.

Informed Consent Statement: Not applicable.

Data Availability Statement: Not applicable.

Acknowledgments: Los autores quieren agradecer la colaboración de la Dorota Małaszkiewicz, Civ. Eng, de la Bialystok University of Technology por el soporte técnico prestado en la realización de los ensayos de microscopía electrónica de barrido (SEM).

Conflicts of Interest: The authors declare no conflict of interest. 


\section{References}

1. Martín-Morales, M.; Zamorano, M.; Ruiz-Moyano, A.; Valverde-Espinosa, I. Characterization of recycled aggregates construction and demolition waste for concrete production following the Spanish Structural Concrete Code EHE-08. Constr. Build. Mater. 2011, 25, 742-748. [CrossRef]

2. Rodríguez, G.; Medina, C.; Alegre, F.J.; Asensio, E.; Sánchez de Rojas, M.I. Assessment of Construction and Demolition Waste plant management in Spain: In pursuit of sustainability and eco-efficiency. J. Clean. Prod. 2015, 90, 16-24. [CrossRef]

3. Instituto Nacional de Estadística. Estadística Sobre Generación De Residuos En El Sector Servicios Y Construcción; Madrid, Spain, 2017. Available online: https:/ / www.ine.es/jaxi/Table.htm?path=/t26/e068/p03/a2017/10/\&file=01001.px\&L=0 (accessed on 16 July 2021).

4. Kabirifar, K.; Mojtahedi, M.; Changxin, C.; Tam, V.W.Y. A conceptual foundation for effective construction and demolition waste management. Clean. Eng. Technol. 2020, 1, 10019. [CrossRef]

5. Yang, D.; Liu, M.; Ma, Z. Properties of the foam concrete containing waste brick powder derived from construction and demolition waste. J. Build. Eng. 2020, 23, 101509. [CrossRef]

6. Prasad, D.; Pandey, A.; Kumar, B. Sustainable production of recycled concrete aggregates by lime treatment and mechanical abrasion for M40 grade concrete. Constr. Build. Mater. 2021, 268, 121119. [CrossRef]

7. Waskow, R.; Gonçalves, V.; Tubino, R.; Passuello, A. Environmental performance of construction and demolition waste management strategies for valorization of recycled coarse aggregate. J. Environ. Manag. 2021, 295, 113094. [CrossRef]

8. Ferrández, D.; Saiz, P.; Morón, C.; Zúñiga-Vicente, J.A. Analysis of the disadvantages associated with the process of reuse of recycled aggregates from construction and demolition waste. In VI International Conference on Technological Innovation in Building; Universidad Politécnica de Madrid: Madrid, Spain, 2021.

9. Etxeberria, M.; Vázquez, E.; Marí, A.; Barra, M. Influence of amount of recycled coarse aggregates and production process on properties of recycled aggregate concrete. Cem. Concr. Res. 2007, 37, 735-742. [CrossRef]

10. Hamed, H.; Tiznobaik, M.; Huda, S.B.; Islam, M.S.; Shahria, M. Recycled aggregate concrete from large-scale production to sustainable field application. Constr. Build. Mater. 2020, 262, 119979. [CrossRef]

11. Kumar Attri, G.; Gupta, R.C.; Shrivastava, S. Impact of recycled concrete aggregate on mechanical and durability properties of concrete paver blocks. Mater. Today Proc. 2021, 42, 975-981. [CrossRef]

12. Gao, D.; Wang, F. Effects of recycled fine aggregate and steel fiber on compressive and splitting tensile properties of concrete. J. Build. Eng. 2021, in press. [CrossRef]

13. Tam, V.W.; Wattage, H.; Le, K.N.; Buteraa, A.; Soomro, M. Methods to improve microstructural properties of recycled concrete aggregate: A critical review. Constr. Build. Mater. 2021, 270, 121490. [CrossRef]

14. Saiz, P.; González, M.; Fernández, F.; Rodríguez, A. Comparative study of three types of fine recycled aggregates from construction and demolition waste (CDW), and their use in masonry mortar fabrication. J. Clean. Prod. 2016, 118, 162-169. [CrossRef]

15. Sánchez de Juan, M. Estudio Sobre La Utilización De Árido Reciclado Para La Fabricación De Hormigón Estructural. Ph.D. Thesis, Universidad Politécnica de Madrid, Madrid, Spain, 2004.

16. Morón, C.; Ferrández, D.; Saiz, P.; Yedra, E. Measuring system of capillary rising damp in cement mortars. Measurement 2019, 135, 252-259. [CrossRef]

17. Morón, C.; Saiz, P.; Ferrández, D.; García-Fuentevilla, L. New System of Shrinkage Measurement through Cement Mortars Drying. Sensors 2017, 17, 522. [CrossRef]

18. Pacheco, J.N.; de Brito, J.; Chastre, C.; Evangelista, L. Probabilistic Conversion of the Compressive Strength of Cubes to Cylinders of Natural and Recycled Aggregate Concrete Specimens. Materials 2019, 12, 280. [CrossRef] [PubMed]

19. Raini, I.; Jabrane, R.; Mesrar, L.; Akdim, M. Evaluation of mortar properties by combining concrete and brick wastes as fine aggregate. Case Stud. Constr. Mater. 2020, 113. [CrossRef]

20. Ferrández, D.; Saiz, P.; Morón, C.; Diaz, J.P. Research of recycled mortars behaviour towards impact noise. Inf. Construcción 2019, 71, e292. [CrossRef]

21. Sáiz Martínez, P. Utilización De Arenas Procedentes De Residuos De Construcción Y Demolición, Rcd, En La Fabricación De Morteros De Albañilería. Ph.D. Thesis, Universidad Politécnica de Madrid, Madrid, Spain, 2015.

22. Betolesi, E.; Torres, B.; Adam, J.M.; Calderón, P.A.; Moragues, J.J. Effectiveness of Textile Reinforced Mortar (TRM) materials for the repair of full-scale timbrel masonry cross vaults. Eng. Struct. 2020, 248, 118532. [CrossRef]

23. Ferrández, D.; Saiz, P.; Morón, C.; Atanes-Sánchez, E. Comparative analysis of fibre-reinforced plasters for the production of precast elements. DYNA 2020, 95, 333-3336. [CrossRef]

24. Jao, D.; Shi, C.; Yuan, Q.; Zhu, D.; Schuteer, D. Effects of rotational shearing on rheological behavior of fresh mortar with short glass fiber. Constr. Build. Mater. 2019, 203, 314-321. [CrossRef]

25. Santarelli, M.L.; Sbardella, F.; Zuena, M.; Tirillo, J.; Sarasini, F. Basalt fiber reinforced natural hydraulic lime mortars: A potential bio-based material for restoration. Mater. Des. 2014, 64, 398-406. [CrossRef]

26. Nguyen, M.H.; Hirano, Y.; Nakajima, A.; Fujikura, S.; Niimura, R. Experimental evaluation of the shear capacity of perfobond strips with steel fiber-reinforced mortar in narrow joint structures. Structures 2020, 28, 1173-1186. [CrossRef]

27. Donnini, J.; Bellezze, T.; Corinaldesi, V. Mechanical, electrical and self-sensing properties of cementitious mortars containing short carbon fibers. J. Build. Eng. 2018, 20, 8-14. [CrossRef] 
28. Rajaei, S.; Shoaei, P.; Shariati, M.; Ameri, F.; Reza, H.; Behforouz, B.; de Brito, J. Rubberized alkali-activated slag mortar reinforced with polypropylene fibres for application in lightweight thermal insulating materials. Constr. Build. Mater. 2021, $270,121430$. [CrossRef]

29. Chen, W.; Xie, Y.; Li, B.; Li, B.; Wang, J.; Thom, N. Role of aggregate and fibre in strength and drying shrinkage of alkali-activated slag mortar. Constr. Build. Mater. 2021, 133, 124002. [CrossRef]

30. Candamano, S.; Crea, F.; Coppola, L.; de Luca, P.; Coffetti, D. Influence of acrylic latex and pre-treated hemp fibers on cementbased mortar properties. Constr. Build. Mater. 2021, 273, 121720. [CrossRef]

31. Quiñones-Bolaños, E.; Gómez, M.; Mouthon-Bello, J.; Sierra-Vitola, L.; Berardi, U.; Bustillo-Lecompte, C. Potential use of coconut fibre modified mortars to enhance thermal comfort in low-income housing. J. Environ. Manag. 2021, 277, 111503. [CrossRef] [PubMed]

32. Ince, C.; Tayançlı, S.; Derogar, S. Recycling waste wood in cement mortars towards the regeneration of sustainable environment. Constr. Build. Mater. 2021, 299, 123891. [CrossRef]

33. Govind-Chandrasekaran, R.; Ramakrishna, G. Experimental investigation on mechanical properties of economical local natural fibre reinforced cement mortar. Mater. Today Proc. 2021, in press. [CrossRef]

34. Yang, H.; Song, H.; Zhang, S. Experimental investigation of the behavior of aramid fiber reinforced polymer confined concrete subjected to high strain-rate compression. Constr. Build. Mater. 2015, 95, 143-151. [CrossRef]

35. Dhanesh, S.; Senthil Kumar, K.; Maruthut, P.; Rejumon, R.; Usmansha, G.S. Experimental investigation of strength of Aramid kelvar and chopped carbon reinforced concrete beam. Mater. Today Proc. 2021, in press. [CrossRef]

36. Ismail, N.; de Rooij, M.B.; de Vries, E.G.; Mohd Zini, N.H.; Schipper, D.J. Friction between single aramid fibres under pre-tension load. Tribol. Int. 2019, 137, 236-245. [CrossRef]

37. Jie Dong, F.G.; Tang, M.; Li, X.; Li, M.; Zhao, X.; Zhang, Q. High-tenacity and high-modulus polyimide fibers containing benzimidazole and pyrimidine units. React. Funct. Polym. 2019, 141, 112-122. [CrossRef]

38. Caggegi, C.; Carozzi, F.G.; De Santis, S.; Fabbrocino, F.; Focacci, F.; Hojdys, L.; Lanoye, E.; Zuccarino, L. Experimental analysis on tensile and bond properties of $\mathrm{PBO}$ and aramid fabric reinforced cementitious matrix for strengthening masonry structures. Compos. Part B 2017, 127, 175-195. [CrossRef]

39. Nie, L.; Xu, J.; Luo, X.; Chen, H.; Chang, S.; Wang, T.; Liu, G. Study of aramid and carbon fibers on the tensile properties of early strength cement mortar. IOP Conf. Ser. Earth Environ. Sci. 2019, 267, 032009. [CrossRef]

40. Slebi-Acebedo, J.C.; Lastra-González, P.; Castro-Fresno, D.; Bueno, M. An experimental laboratory study of fiber-reinforced asphalt mortars with polyolefin-aramid and polyacrylonitrile fibers. Constr. Build. Mater. 2020, 248, 118622. [CrossRef]

41. Ministerio de la Presidencia. Instrucción Para La Recepción De Cementos (rc-08); Boletín Oficial del Estado (BOE): Madrid, Spain, 2016; p. 153.

42. García-Meseguer, A.; Morán-Cabré, F.; Arroyo-Portero, J.C. Hormigón Armado, Jiménez Montoya, 15th ed.; Editorial GG: Barcelona, Spain, 2011; ISBN 978-84-252-2307-5.

43. Saiz, P.; Ferrández, D.; Morón, C.; Fernández, F. Behaviour of masonry mortars fabricated with recycled aggregate towards moisture. DYNA 2018, 94, 442-446. [CrossRef]

44. Ramachandran, V.S.; Paroli, R.M.; Beaudoin, J.J.; Delgado, A.H. Formation and Hydration of Cement and Cement Compounds. In Handbook Therm; Anal. Constr. Mater.; William Andrew Publishing: New York, NY, USA, 2002.

45. Piña, C.; Atanes Sánchez, E.; del Río, M.; Viñas, C.; Vidales, A. Feasibility of the use of mineral wool fibres recovered from CDW for the reinforcement of conglomerates by study of their porosity. Constr. Build. Mater. 2018, 191, 460-468. [CrossRef]

46. UNE-EN 13139: 2003. Aggregates for Mortar; Aenor International: Madrid, Spain, 1999.

47. UNE-EN 933-1: 2012. Tests for Geometrical Properties of Aggregates-Part 1: Determination of Particle Size Distribution-Sieving Method; Aenor International: Madrid, Spain, 1999.

48. UNE-EN 146404: 2018. Aggregates for Concrete. Determination of the Coefficient of Friability of the Sands; Aenor International: Madrid, Spain, 1999.

49. UNE-EN 1097-3: 1999. Tests for Mechanical and Physical Properties of Aggregates_Part 3: Determination of Loose Bulk Density and Voids; Aenor International: Madrid, Spain, 1999.

50. UNE-EN 1097-6: 2014. Tests for Mechanical and Physical Properties of Aggregates_Part 6: Determination of Particle Density and Water Absorption; Aenor International: Madrid, Spain, 1999.

51. Hassan, R.Y.; Ali Faroun, G.; Mohamed, S.K. Mechanical properties of concrete made with coarse and fine recycled aggregates. Mater. Today Proc. 2021, in press. [CrossRef]

52. Kim, J. Properties of recycled aggregate concrete designed with equivalent mortar volume mix design. Constr. Build. Mater. 2021, 301, 124091. [CrossRef]

53. Eckert, M.; Oliveira, M. Mitigation of the negative effects of recycled aggregate water absorption in concrete technology. Constr. Build. Mater. 2017, 133, 416-424. [CrossRef]

54. Rangel, C.S.; Toledo-Filho, R.D.; Amario, M.; Pepe, M.; Polisseni, G.C.; Puente de Andrade, G. Generalized quality control parameter for heterogenous recycled concrete aggregates: A pilot scale case study. J. Clean. Prod. 2019, 208, 589-601. [CrossRef]

55. UNE-EN 933-2/1M:1999. Test for Geometrical Properties of Aggregates. Part 2: Determination of Particle Size Distribution. Test Sieves, Nominal Size of Apertures; Aenor International: Madrid, Spain, 1999. 
56. NBE FL-90. Norma Básica De Edificación. Muros Resistentes De Fábrica De Ladrillo; BOE-Agencia Estatal Boletín Oficial del Estado: Madrid, Spain, 1991.

57. Koushkbaghi, M.; Kazemi, M.J.; Mosavi, H.; Mohseni, E. Acid resistance and durability properties of steel fiber-reinforced concrete incorporating rice husk ash and recycled aggregate. Constr. Build. Mater. 2019, 202, 266-275. [CrossRef]

58. Nedeljković, M.; Visser, J.; Nigland, T.G.; Valke, S.; Schlangen, E. Physical, chemical and mineralogical characterization of Dutch fine recycled concrete aggregates: A comparative study. Constr. Build. Mater. 2020, 270, 121475. [CrossRef]

59. Ulsen, C.; Kahn, H.; Hawlitscschek, G.; Masini, E.A.; Angulo, S.C.; John, V.M. Production of recycled sand from construction and demolition waste. Constr. Build. Mater. 2013, 40, 1168-1173. [CrossRef]

60. Li, L.G.; Zhao, Z.W.; Zhu, J.; Kwan, A.K.H.; Zeng, K.L. Combined effects of water film thickness and polypropylene fibre length on fresh properties of mortar. Constr. Build. Mater. 2018, 174, 586-593. [CrossRef]

61. ElNemr, A. Generating water/binder ratio -to- strength curves for cement mortar used in Masnory walls. Constr. Build. Mater. 2019, 233, 117249. [CrossRef]

62. de Isabel, C., II. Informe Anual Sobre La Calidad Del Agua En Madrid; Canal de Isabel II: Madrid, Spain, 2012.

63. Morón, A.; Ferrández, D.; Saiz, P.; Vega, G.; Morón, C. Influence of Recycled Aggregates on the Mechanical Properties of Synthetic Fibers-Reinforced Masonry Mortars. Infrastructures 2021, 6, 84. [CrossRef]

64. Xu, C.; Li, H.; Dong, B.; Yang, X. Chlorine immobilization and performances of cement paste/mortar with C-S-Hs-PCE and calcium chloride. Constr. Build. Mater. 2020, 262. [CrossRef]

65. Piña-Ramírez, C. Comportamiento Físico-Mecánico y Térmico de los Morteros de Cemento Aditivados con Fibras Minerales Procedentes de Residuos de Construcción y Demolición. Ph.D. Thesis, Universidad Politécnica de Madrid, Madrid, Spain, 2018. [CrossRef]

66. Bustos-García, A. Morteros con Propiedades Mejoradas de Ductilidad por Adición de Fibras de Vidrio, Carbono y Basalto. Ph.D. Thesis, Universidad Politécnica de Madrid, Madrid, Spain, 2018. [CrossRef]

67. UNE-EN 196-1:2018. Methods of Testing Cement-Part 1: Determination of Strength; Aenor International: Madrid, Spain, 1999.

68. UNE-EN 1015-2:1999/A1:2007. Methods of Test for Mortar for Masonry_Part 2: Bulk Sampling of Mortars and Preparation of Test Mortars; Aenor International: Madrid, Spain, 1999.

69. Máster Builders Solutions España, S.L.U. MasterGlenium SKY 604: Aditivo Superplastificante/Reductor De Agua De Alta Actividad Para Hormigón Preparado; Master Builders Solutions España, S.L.U.: Barcelona, Spain, 2021.

70. UNE-EN 1015-11:2000/A1:2007. Methods of Test for Mortar for Masonry_Part 11: Determination of Flexural and Compressive Strength of Hardened Mortar; Aenor International: Madrid, Spain, 1999.

71. UNE-EN 1015-12:2016. Methods of Test for Mortar for Masonry_Part 12: Determination of Adhesive Strength of Hardened Rendering and Plastering Mortars on Substrates; Aenor International: Madrid, Spain, 1999.

72. UNE-EN 1015-18:2003. Methods of Test for Mortar for Masonry—Part 18: Determination of Water Absorption Coefficient Due to Capillary Action of Hardened Mortar; Aenor International: Madrid, Spain, 1999.

73. UNE 80-112-89. Test Methods. Cement. Determination of Shrinkage and Swelling in Water; Aenor International: Madrid, Spain, 1999.

74. UNE-EN 12371:2011. Natural Stone Test Methods_Determination of Frost Resistance; Aenor International: Madrid, Spain, 1999.

75. Peña, D. Regresión Y Diseño De Experimentos; Alianza Editorial: Madrid, Spain, 2010; ISBN 9788420693897.

76. Shang, J.; Dai, J.G.; Zhao, T.J.; Guo, S.Y.; Zhang, P.; Mu, B. Alternation of traditional cement mortars using fly ash-based geopolymer mortars modified by slag. J. Clean. Prod. 2018, 203, 746-756. [CrossRef]

77. Zhou, B.; Zhang, M.; Wang, L.; Ma, G. Experimental study on mechanical property and microstructure of cement mortar reinforced with elaborately recycled GFRP fiber. Cem. Concr. Compos. 2021, 117. [CrossRef]

78. Bustos García, A. Estado del conocimiento de los morteros de cemento reforzados con fibras de acero, vidrio, polipropileno, basalto y acrílicas. In Congreso Internacional de Innovación Tecnológica en Edificación (CITE 2016); Escuela Técnica Superior de Edificación: Madrid, Spain, 2016; pp. 140-141. ISBN 978-84-16397-28-0.

79. Angelin, A.F.; Cecche Lintz, R.C.; Gachet-Barbosa, L.A.; Osório, W.I. The effects of porosity on mechanical behavior and water absorption of an environmentally friendly cement mortar with recycled rubber. Constr. Build. Mater. 2017, 151, 534-545. [CrossRef]

80. Chen, J.K.; Jiang, M.Q. Long-term evolution of delayed ettringite and gypsum in Portland cement mortars under sulfate erosion. Constr. Build. Mater. 2009, 23, 801-816. [CrossRef]

81. Morón-Barrios, A.; Ferrández, D.; Saiz, P.; Atanes-Sánchez, E.; Morón, C. Study of the properties of lime and cement mortars made from recycled ceramic aggregate and reinforced with fibers. J. Build. Eng. 2021, 35. [CrossRef]

82. Piña, C.; Vidales, A.; Serrano, R.; del Rio, M.; Atanes-Sánchez, E. Analysis of fire resistance of cement mortars with mineral wool from recycling. Constr. Build. Mater. 2020, 265. [CrossRef]

83. Piña, C.; del Rio, M.; Viñas, C.; Vidales, A.; Kosior-Kazberuk, M. Analysis of the mechanical behaviour of the cement mortars with additives of mineral wool fibres from recycling of CDW. Constr. Build. Mater. 2020, 210, 56-62. [CrossRef]

84. Saiz, P.; González-Cortina, M.; Fernández, F. Characterization and influence of fine recycled aggregates on masonry mortars properties. Mater. Construcción 2015, 65. [CrossRef]

85. Huang, Q.; Zhu, X.; Xiong, G.; Wang, C.; Liu, D.; Liang, Z. Recycling of crushed waste clay brick as aggregates in cement mortars: An approach from macro- and micro-scale investigation. Constr. Build. Mater. 2021, 274. [CrossRef]

86. Gheni, A.A.; Alghazali, H.H.; ElGawadi, M.A.; Myres, J.J.; Feys, D. Durability properties of cleaner cement mortar with by-products of tire recycling. J. Clean. Prod. 2019, 213, 1135-1146. [CrossRef] 
87. Saiz, P.; Ferrández, D.; Morón, C.; Payán, A. Comparative study of the influence of three types of fibre in the shrinkage of recycled mortar. Mater. Construcción 2018, 68. [CrossRef]

88. Tong, Y.; Zhao, S.; Ma, J.; Wang, L.; Zhang, Y.; Gao, Y.; Min-Xie, Y. Improving cracking and drying shrinkage properties of cement mortar by adding chemically treated luffa fibres. Constr. Build. Mater. 2014, 71, 327-333. [CrossRef] 